\title{
Full mouth rehabilitation of severely worn dentition using posterior implants: a clinical report
}

\author{
Hyun-Sun Kang, Cheol-Won Lee, Won-Sup Lee, Su-Young Lee* \\ Department of Prosthodontics, Seoul St. Mary's Dental Hospital, The Catholic University of Korea, Seoul, Republic of Korea
}

This clinical report focuses on the treatment of a patient with esthetic and functional impairments due to severe worn dentition. Absence of posterior support for a prolonged period require comprehensive prosthetic restoration. Accurate clinical and radiographic examinations, diagnostic wax-up, and occlusal vertical dimension evaluation were performed and the degree of patient adaptability was evaluated using an interim restoration. After 8 weeks of stabilization with interim restoration and confirmation of absence of any abnormal findings, definitive prostheses were fabricated. Satisfactory functional and esthetic outcomes were observed after 6 months of follow-up. (J Dent Rehabil Appl Sci 2016;32(3):255-62)

Key words: tooth wear; vertical dimension; full mouth rehabilitation

\section{서론}

통상적으로 비우식성의 치질 상실은 원인과 상실 의 양상에 따라 다음과 같은 네 가지로 분류된다. 교모 (attrition)은 치아간의 기계적인 마찰을 통하여 치질 상 실이 일어난 경우를 이르며, 마모(abrasion)는 치아 외 의 물리적인 접촉을 통한 경우를 지칭한다. 굴곡파절 (abfraction)은 날카로운 쐐기 형태의 치경부 결손을 말 하며, 부식(erosion)은 화학적 작용을 통하여 치질이 상 실된 경우를 일컫는다. ${ }^{1,2}$ Crother는 이러한 치질상실은 하나의 기전에 의하여 유발되지 않으며, 여러 가지 원인 의 상호작용을 통하여 일어나는 현상으로 보았기 때문에 통칭하여 ‘치아 마모(tooth wear)'라는 용어가 적절하다 고 보고 하였다. ${ }^{3}$

점진적이며 지속적인 치아의 마모는 개인의 일평생을 거쳐 진행이 되나, 반대로 과도한 마모가 특정 시기에 일 어나기도 한다. Smith와 Knight는 이러한 종류의 치아 마

*Correspondence to: Su-Young Lee

Clinical Assistant Professor, Department of Prosthodontics, Seoul St. Mary's Hospital, The Catholic University of Korea, Banpo-daero 222, Seocho-gu, Seoul, 06591, Republic of Korea

Tel: +82-2-2258-1795, Fax: +82-2-2258-2374, E-mail: Isuyoung@daum.net Received: August 2, 2016/Last Revision: August 31, 2016/Accepted: September 9 , 2016
모를 병적 치아 마모라고 하였으며 치료를 요한다고 하 였다. ${ }^{4}$ 병적 치아 마모는 어느 시기의 연령에나 일어날 수 있으나, 나이가 증가함에 따라 빈도가 증가하는 경향이 있다. ${ }^{5}$ Donachie와 Walls는 마모를 진단하는 기준으로 연 령을 추가하였으며, 연령에 따른 정상적인 생리적 마모보 다 심하게 진행된 치아 마모를 병적 치아 마모라고 정의 하였다. ${ }^{6}$

생리적 마모의 경우, 마모의 정도는 심각하지 않고, 치 아와 치조골의 보상적 기전을 통하여 적절한 수직 고경 이 유지된다. ${ }^{7-9}$ 반대로, 과도한 병적 치아 마모는 보상적 기전보다 마모의 진행 속도가 빠르기 때문에, 수직 고경 상실을 포함하여 전치부 마모 또는 파절과 같은 심미적 문제를 유발하고 사회 생활에 지장을 준다. 또한, 저작 효율이 감소되며, 치질 상실로 인한 과민증, 상아질 노출 로 인한 치아 변색, 병적 치수염이 유발될 수 있다. 전방 유도의 상실은 근신경계에 과도한 부하를 야기하며, 심 한 경우 턱관절 질환으로 이어지기도 한다. 무엇보다, 과

Copyright $(C) 2016$ The Korean Academy of Stomatognathic Function and Occlusion. (c) It is identical to Creative Commons Non-Commercial License. 
도한 측방압이 구치부에 집중이 되고, 이것은 치아의 예 후를 불량하게 하며, 수복물 파절과 같은 보철적 합병증 을 증가시킨다. ${ }^{10}$

부식과 마모로 인하여 광범위하게 치질 상실이 발생된 환자는 완전 구강 회복 술식이 요구되는데, 이때 환자의 수직 고경 증가 여부는 신중하게 고려되어야 한다. 병적 치아 마모는 보상적 기전보다 마모의 진행 속도가 빠르 기 때문에, 수직 고경 상실량을 신중히 평가하여 거상 정 도를 결정하여야 한다. ${ }^{11-13}$ Turner와 Missirlia는 수직 고 경 상실 정도와 보철 수복을 위하여 필요한 공간을 고려 하여, 치료 방향을 잡을 것을 권하고 있다. ${ }^{14}$ 수직 고경의 회복은 보철 수복을 위한 공간을 확보하고, 교합과 심미 성을 개선하기 위하여 종종 필요하다. ${ }^{14,15}$ 환자의 전반적 인 분석을 통하여, 수직 고경의 거상량을 결정하여야 하 며, 원래의 수직 고경으로 회복할 경우, 턱관절에 끼치는 영향이나 근신경 활동, 발음 등에 끼치는 영향을 주의 깊 게 관찰하여야 한다. ${ }^{16}$

본 증례는 구치부의 상실을 오랜 기간 방치하여 심한 마모가 진행된 환자를 구치부 임플란트를 이용하여 수직
고경을 회복하였으며, 완전 구강 회복술을 통하여 기능 및 심미적으로 만족스러운 결과를 얻었기에 보고하고자 한다.

\section{증례보고}

\section{환자 개요 및 주소}

상기 환자는 62세의 여성으로 심한 마모로 인하여 이 가 짧아 보기 싫다는 주소로 내원하였다. 구치부 치아를 상실한 뒤 오랜 기간 방치한 채로 전치부로만 저작하여 전치부까지 마모가 심하게 진행된 것 같다고 진술 하였 다. 특이할만한 의과적 및 치과적 병력은 갖고 있지 않았 으며, 평소 식습관으로 딱딱한 음식을 즐겨 먹는다고 하 였다. 집중 시 이를 꽉 깨무는 악습관이 있었다.

\section{임상 검사 및 진단 분석}

상악전치부 구개면 및 절단면의 마모가 관찰되었다
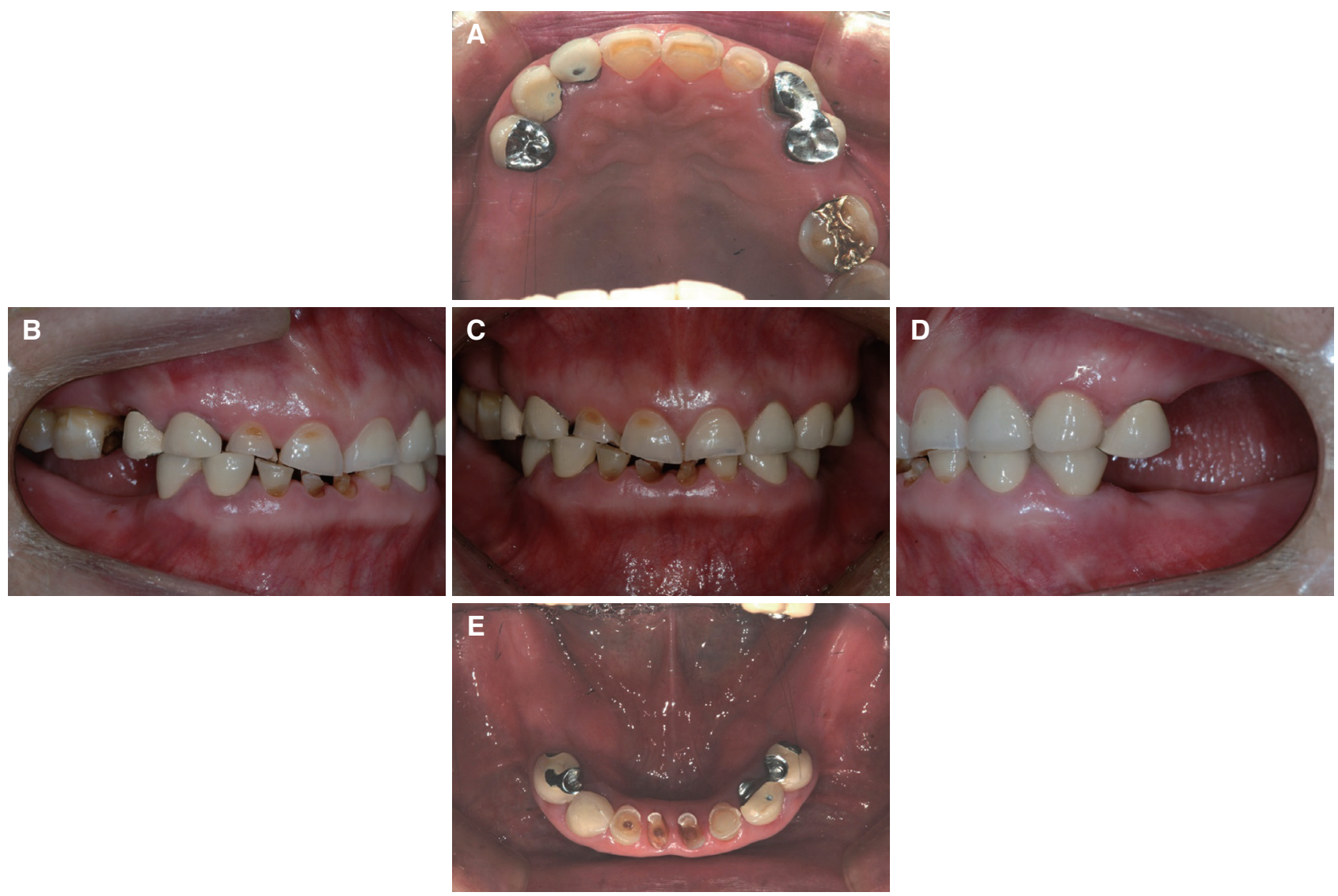

Fig. 1. Pre-treatment state. (A) Maxillary occlusal view, (B) Right lateral view, (C) Frontal view, (D) Left lateral view, (E) Mandibular occlusal view. 
(Fig. 1). 하악 전치부는 법랑질이 마모되면서 상아질이 노출된 양상을 띄었으며, 마모된 면은 반대 상악 대합치 의 날카로운 부분과 맞물린 형태를 보였다. 상악 구개측 치아 마모로 전방 및 측방 유도가 상실되었고, 하악은 마 모된 치아면을 따라 유도되었다. 또한 상하악 전치부 절 단면의 마모로 비심미적인 상태였다. 소구치 부위도 마 모가 진행되고 있었으며, 금속도재관으로 수복된 상태라 그 양상은 자연치만큼 심하진 않았으나 하방의 금속이 노출되거나 편평한 면이 형성되었다. 상악 우측 구치부 는 결손된 대합치로 인해 정출된 양상을 보였다. 방사선 학적 검사 및 임상 진단 결과 치주 상태 및 전반적인 구강 위생 상태는 양호하였다.

안모는 좌우 대칭적이고 동공간선과 구각부는 수평을 보였으며, 교근이 발달한 인상을 주었다. 상순 두께는 정 상적이고, 직선적 측모 형태를 보였다. 미소 시 치아는 6 - 8개 이내를 보이고, 높은 미소선을 보였으며 안면 정중 선과 치아 정중선은 일치하지 않았다.

방사선 검사상 상하악 전치부의 교합면의 법랑질이 마 모된 양상을 보였다. 하악 좌측 제 1 소구치의 경우 포스 트 측벽으로 잔존 치질의 양이 적고 수직 균열이 의심되 어 지대치로 사용하기에는 예후가 불량할 것으로 판단하 고 발치를 결정하였다(Fig. 2). 턱관절 이상을 의심할만한 특이 소견은 없었으며(Fig. 3), 정상범위의 개구 운동을 보였다. 개폐구 시 특별한 턱관절음 등은 관찰되지 않았 다. 악안면근 촉진 시에도 특이 소견은 관찰되지 않았다.

치아는 난원형의 형태로, 상아질 노출로 인하여 황색 으로 보이고 불투명 하였다. 치아의 크기를 분석하였을 때, 절단면 마모로 인하여 평균 동양여성의 중절치, 측절 치, 견치 크기 $10.05 \mathrm{~mm}, 8.37 \mathrm{~mm}, 9.49 \mathrm{~mm}$ 에 비하여 작은 크기를 보였다.

Smith와 Knight의 치아 마모 지표에 의하면 본 환자의

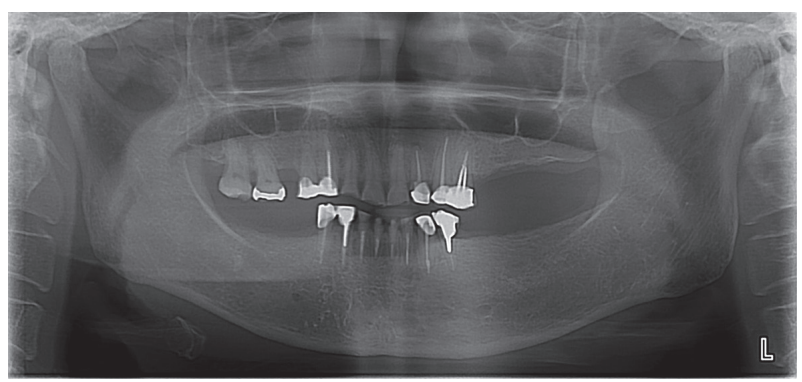

Fig. 2. Initial panoramic radiographic image before treatment.
경우 상악 전치부는 절단면 마모를 동반한 상아질 $1 / 3$ 이하의 마모를 보이는 2 등급, 하악 전치부는 치수까지 침 범한 상아질 마모를 보이는 4 등급으로 분류하였다. ${ }^{4}$

환자는 구치부의 상실로 인한 수직 지지의 부재로 인 하여 상하악 전치부의 상아질이 노출되는 병적 치아마모 를 보이고, 수직고경이 상실되었다고 판단할 수 있었다. 이를 바탕으로 문제 목록을 작성해보면 상하악 과도한 치아의 마모로 인해 1) 수직고경의 감소, 2) 전방 및 측방 유도 상실, 3) 비심미적인 전치부 형태, 4) 상아질색의 치 아변색 등을 들 수 있다.

Turner와 Missirlian에 따르면 수직고경 상실 유무와 보철 수복 공간이 충분한지 유무에 따라 세가지 분류로 나눠서 치료 방향을 잡을 것을 권유하고 있다. 본 증례는 수직 고경 상실을 동반한 범주 1로서, 수직 고경이 원래 대로 회복하는 경우, 환자는 회복된 수직고경에 빠르고 쉽게 적응할 수 있다고 보고되었다. 따라서 전반적인 마 모를 보이는 환자에서는 변화된 수직고경에 적응 여부를 판단하기 위해서 스플린트를 제작하여 평가하는데, 범주 1 의 경우 스플린트도 필요치 않고 6 - 8주의 임시수복 기 간동안 심미 및 기능 평가가 가능하다.

\section{치료계획}

본 증례의 치료목표는 적절한 수직고경을 회복하여 근 신경계적으로 조화로운 저작 기능 회복, 심미적인 수복 물 제작, 적절한 전방 및 측방 유도를 확립한 상호 보호 교합 양식의 부여, 추가적인 마모 진행을 막는 유지관리 로 잡았다.

마운팅된 진단 모델 분석 결과 심한 마모로 인하여 심 미적인 보철 수복을 위한 악간 공간이 부족하였기 때문 에, 수직 고경 증가를 동반한 완전 구강 회복술을 계획하
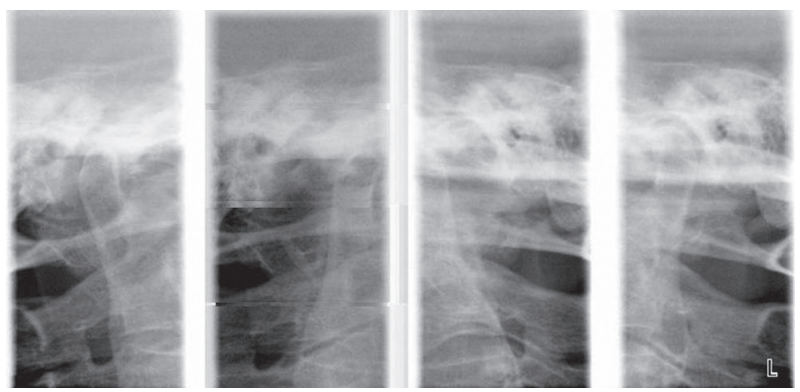

Fig. 3. Initial TMJ series. No evidence of pathologic change was seen. 
였다. 안정위시 악간 공간이 약 $5 \mathrm{~mm}$ 정도로 측정되었 으며 환자의 안모분석과 자유 공극을 참고하여 전체 심 미적인 보철 수복을 위하여 제 1 소구치 기준으로 $2 \mathrm{~mm}$ 의 거상량이 필요하다고 판단하였다.

구치부의 상실로 인한 구치부 수직 지지의 부재는 임플 란트를 식립하여 재확립하기로 하였다. 회복된 교합 고 경을 기준으로 상하악 전치부의 경우 단일 완전 도재관 수복을 하고 교합력을 많이 받는 상하악 구치부는 금속 도재관 수복을 계획하였다. 상악 우측 제 2 대구치는 정출 된 양상이 관찰되어 거상하였을 때 필요한 양만큼 교합 면 삭제를 시행하고 그 양이 과도할 때 근관치료 시행 후 보철 수복을 하는 것으로 계획하였다. 교합양식은 상호 보호 교합을 부여하기로 하였다.

\section{치료 과정}

반조절성 교합기상에서 전치 유도핀을 이용하여 $2 \mathrm{~mm}$ 거상하여 이를 기준으로 1 차 진단 납형을 제작 하였다 (Fig. 4). 일차 진단 납형으로 임시수복물을 자가 중합 레 진(Alike, GC Co., Tokyo, Japan)을 사용하여 제작하였다. 진단 납형의 형태로 치아 형성 가이드를 제작하고 이를 기준으로 치아 삭제를 시행하였다. 치아형성을 마무리 하고 일차 임시수복물을 장착하였다. 진단 납형을 기준 으로 스텐트를 제작하여 상하악 구치부 임플란트를 식립 하고 2 차 수술까지 약 3 달간의 경과관찰을 가지면서 임 상재평가를 시행하였다. 상하악 전치부 중앙선이 일치되 지 않는 점을 환자는 받아들였다.

임플란트 2 차 수술 후 환자는 하악 전치부의 치아 길이 가 더 길게 보이기를 원하였다. 일차 임시치아를 인상 채

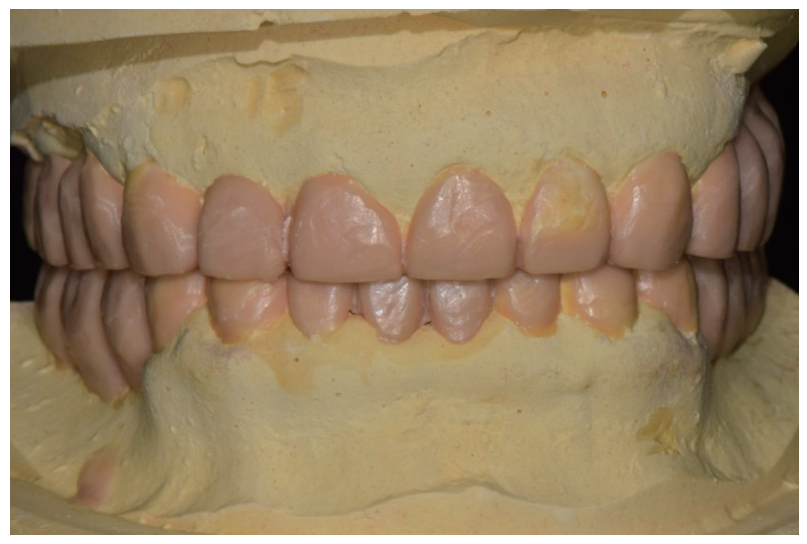

Fig. 4. Primary diagnostic wax-up.
득하여, 수정사항을 표시한 뒤, 일차 임시 수복물의 길이 를 더 늘리면서 치아크기를 재조정하여, 2차 진단 납형을 제작하였다(Fig. 5). 이를 기준으로 수술용 형판을 제작 하고, 하악 전치부 치관 연장술을 시행하였다.

치관 연장술을 시행하고 2차 임시수복물 장착 후 약 8 주간의 평가기간을 가졌다(Fig. 6A). 임플란트 주위 연조 직 치유양상과 새로운 임시 수복물을 통해 결정된 수직 고경에 대한 교합의 안정성 평가가 이루어졌고, 환자는 이 기간동안 불편감 없이 잘 적응 하였으며 기능 및 심미 적으로 문제점이 발견되지 않았다.

2차 임시 수복물을 인상채득하고, 모델 제작하여, 안궁 이전과 교합 채득을 통하여, 반조절성 교합기에 마운팅 하였다. 환자가 적응한 전치 유도를 교합기에 재현하기 위해서 자가 중합 아크릴 레진(Duralay, Reliance Dental Manufacturing Co., Alsip, USA)을 이용하여, 맞춤 절 치 유도판을 제작하였다(Fig. 6B). 최종 치아형성을 하고 폴리비닐실록산 인상체(Imprint II, 3M ESPE, St. Paul, $\mathrm{USA}$ )를 이용하여 정밀한 최종 인상을 채득하였고 작업 모형은 제4형 경석고(GC Jujirock EP, GC Europe N.V., Leuven, Belgium)로 제작하였다. 지대치 색상을 사진으로 남기고 주모형을 교합기에 크로스 마운팅 시행하였다.

최종 수복물 제작을 위하여 주모형과 임시 수복물을 디지털 스캔하여 중첩하였다. 임시 수복물 스캔을 기준 으로 $\mathrm{CAD}$ (computer-aided design) 프로그램(3Shape Dental Manager, 3Shape A/S, Copenhagen, Denmark) 을 이용하여 맞춤형 지대주를 제작 하였다. 제작한 맞춤 형 지대주를 구강내에 시적하여 교합을 재확인하였다. 상하악 전치는 임시 수복물 스캔을 기준으로 되깎기(cutback)를 시행하여 단일구조 지르코니아 블록(BruxZir,

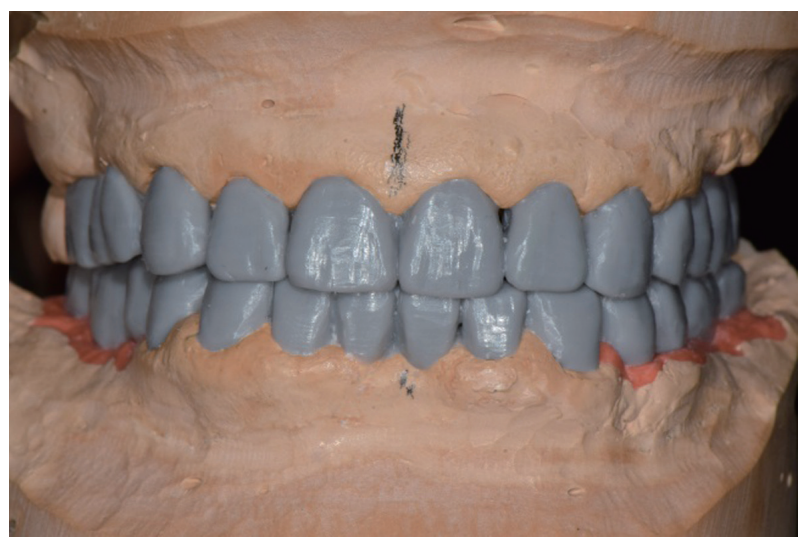

Fig. 5. Secondary diagnostic wax-up. 

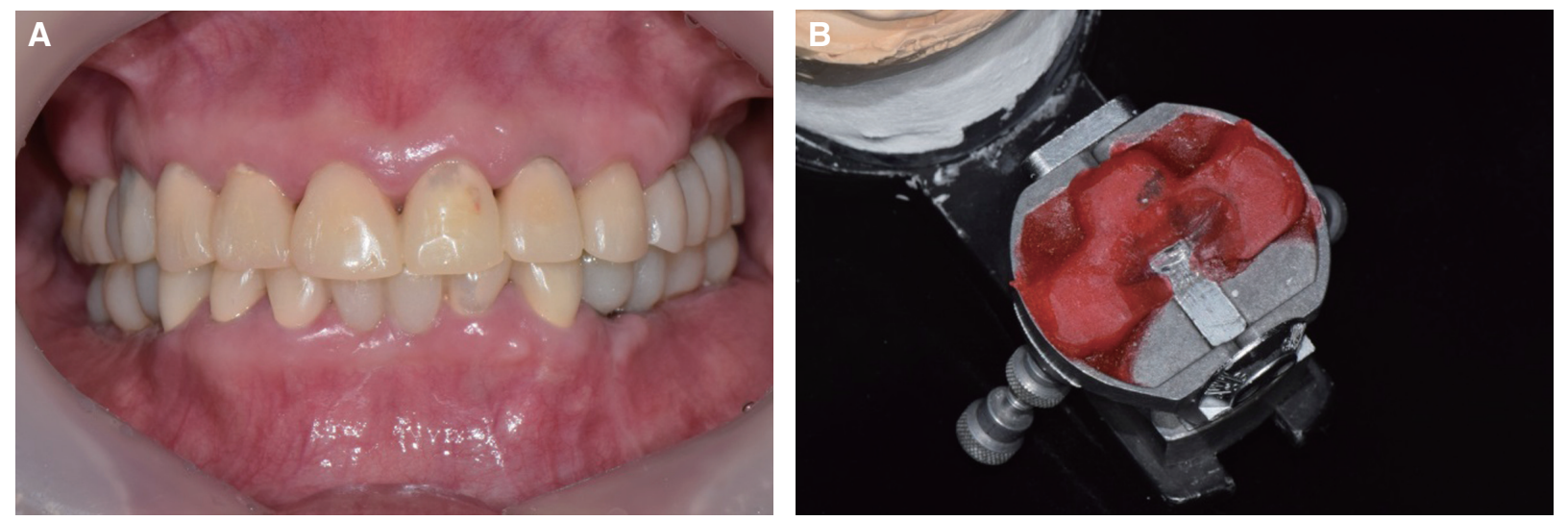

Fig. 6. (A) Provisional restoration, (B) Customized incisal guide table.

Glidewell, Newport Beach, USA)을 이용하여 CAD/ $\mathrm{CAM}$ 방식으로 지르코니아 코핑을 제작하고 글라스 세 라믹을 적층 하였다. 맞춤 절치 유도판을 이용하여 상악 구개측 부위와 하악 전치부 사이의 전방 유도로를 부여 하였다. 상하악 구치부는 환자의 발달된 교근 양상과 식 습관, 이악물기 습관을 고려하여 금속 교합면의 비귀금속
합금 금속도재관으로 제작하였다. 교합양식은 상호보호 교합 양식을 부여하였다. 전치부 완전도재관의 경우 샌드 블라스팅 처리를 하고 레진 시멘트(RelyX Unicem, 3M ESPE, Seefeld, Germany)로 접착하였으며, 구치부 금 속도재관은 레진 강화형 글래스아이오노머 시멘트 $(\mathrm{GC}$ Fuji CEM 2, GC Co.)로 최종 접착하였다(Fig. 7). 최종적
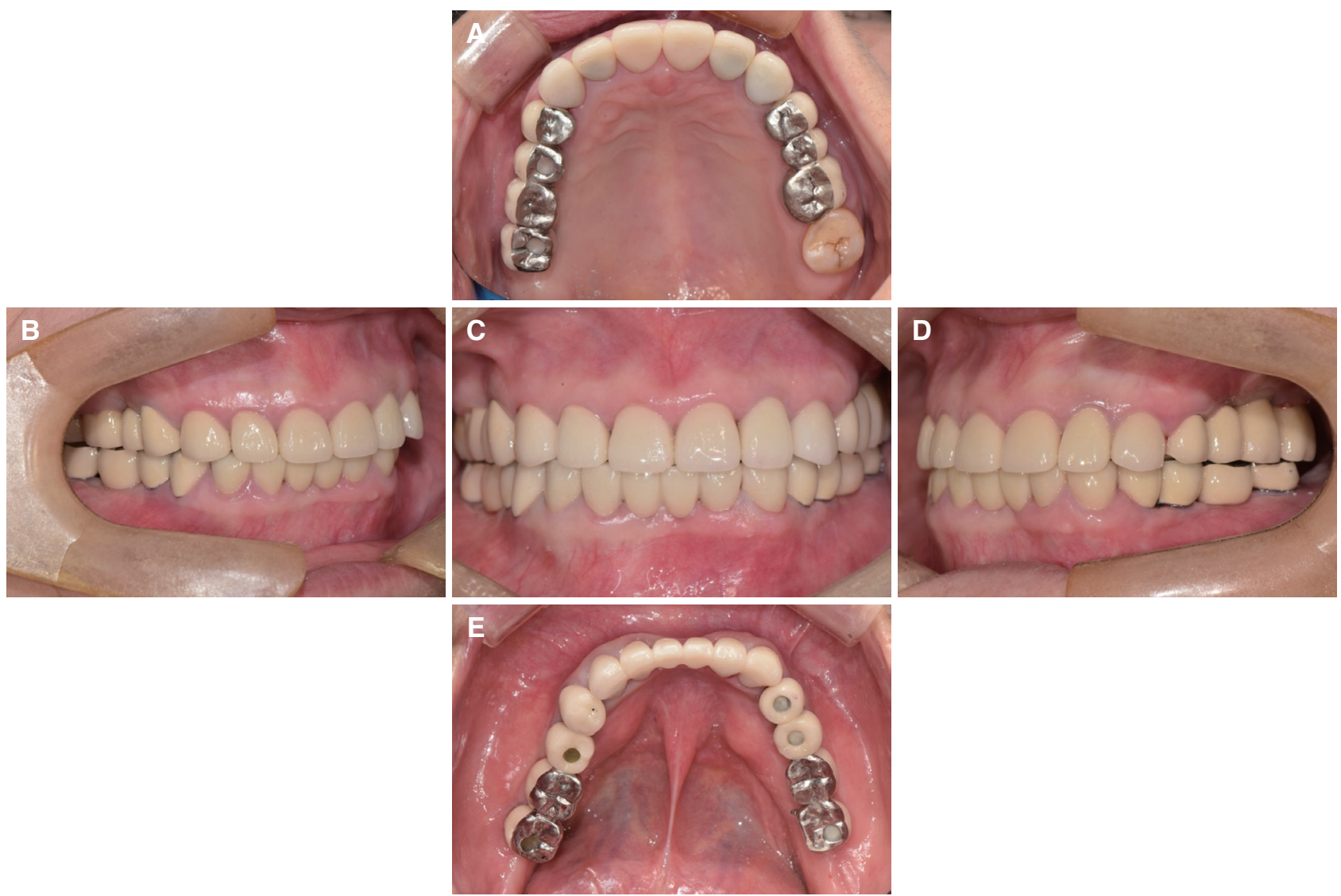

Fig. 7. Final prostheses delivery. (A) Maxillary occlusal view, (B) Right lateral view, (C) Frontal view, (D) Left lateral view, (E) Mandibular occlusal view. 


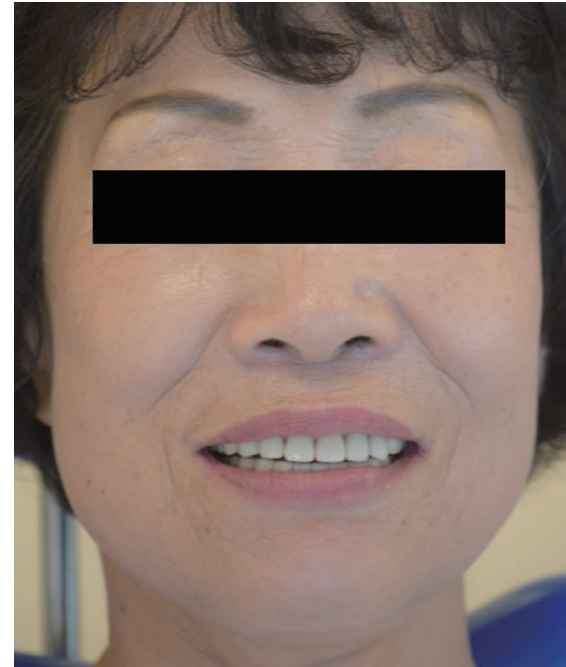

Fig. 8. Analysis of the smile line.

으로 적절한 전치유도가 재현되고 측방운동 시 구치부가 이개되는 상호 보호 교합을 확인하였다. 최종 보철 수복 후 마우스 가드 장착을 지시하여 비기능적인 힘에 의한 보철물 파절을 방지하였으며 측두하악관절 방사선 사진 을 재촬영하여 치아와 턱관절에 이상소견이 나타나지 않 고 안정적으로 유지됨을 재확인하였다.

교합조정 및 구강 위생 교육을 동반한 주기적인 경과 관찰을 시행하였고, 교합 안정 장치를 제작하여 이갈이 에 의한 보철물의 손상을 방지하였다. 보철물 장착 후 약 6 개월간의 임상적, 방사선학적 검사 결과, 환자와 술자 모두 기능 및 심미적으로 만족할 만한 결과를 얻을 수 있 었다.

\section{고찰}

최후방 구치부의 상실은 수직적 지지의 부재로 인하여 하악의 변위를 유발하며, 수직고경의 상실과 함께 전치 부의 마모를 포함한 전반적인 마모로 진행하게 된다. 상 실된 교합 고경의 양을 주의 깊게 평가하여 거상량을 결 정하였으며, 구치부 임플란트 식립을 통하여 원래의 수 직고경으로 회복하였다. 임플란트 임시 보철물은 재료 의 첨가 및 삭제를 통해 변화된 수직고경에 대한 환자의 적응 정도를 반영하기 용이하였다. 임시 수복물 상태에 서 심미적, 기능적 만족을 확인하였으며 하악위의 안정을 확인하고 최종 보철물 수복을 진행하였다.
부족한 보철물 수복 공간은 교합 거상을 통하여 확보 하였고, 상호보호교합을 형성하여 구치부 임플란트에 과 도한 측방힘이 가해지지 않도록 하였다. 비기능적 악습 관을 고려하여 최종 보철물의 도재 파절 예방을 위하여 야간 교합 안정장치를 사용 중이며 지속적인 경과 관찰 이 요구된다.

\section{결론}

본 증례에서는 전반적인 마모를 가진 환자에서 구치부 지지, 마모의 병력, 악간 공극, 및 안모 평가, 치관 길이 평 가 등의 검사를 이용하여 수직 교합 고경을 평가하였다. 이를 바탕으로 진단납형을 제작하여 교합 회복을 결정하 고 임시 보철물을 제작하여 교합 회복에 대한 환자의 적 응을 평가한 후, 특이할 만한 이상 소견이 없는 것을 확인 하고 최종 보철물을 제작하여 장착 하였다. 일련의 치료 과정을 통해 심미적, 기능적으로 만족스러운 결과를 얻 었다(Fig. 8).

\section{References}

1. Grippo JO, Simring M, Schreiner S. Attrition, abrasion, corrosion and abfraction revisited: a new perspective on tooth surface lesions. J Am Dent Assoc 2004;135:1109-18; quiz 1163-5.

2. Verrett RG. Analyzing the etiology of an extremely worn dentition. J Prosthodont 2001;10:224-33.

3. Crothers AJ. Tooth wear and facial morphology. J Dent 1992;20:333-41.

4. Smith BG, Knight JK. A comparison of patterns of tooth wear with aetiological factors. Br Dent J 1984;157:16-9.

5. Bartlett D, Dugmore C. Pathological or physiological erosion - is there a relationship to age? Clin Oral Investig 2008;12 Suppl 1:S27-31.

6. Donachie MA, Walls AW. The tooth wear index: a flawed epidemiological tool in an ageing population group. Community Dent Oral Epidemiol 1996;24: 152-8.

7. Berry DC, Poole DF. Attrition: possible mechanisms of compensation. J Oral Rehabil 1976;3:2016.

8. Dahl BL, Krogstad O. The effect of a partial bite- 
raising splint on the inclination of upper and lower front teeth. Acta Odontol Scand 1983;41:311-4.

9. Ramfjord SP, Blankenship JR. Increased occlusal vertical dimension in adult monkeys. J Prosthet Dent 1981;45:74-83.

10. Muts EJ, van Pelt H, Edelhoff D, Krejci I, Cune M. Tooth wear: a systematic review of treatment options. J Prosthet Dent 2014;112:752-9.

11. Briggs P, Bishop K. Fixed prostheses in the treatment of tooth wear. Eur J Prosthodont Restor Dent 1997;5:175-80.

12. Hemmings KW, Darbar UR, Vaughan S. Tooth wear treated with direct composite restorations at an increased vertical dimension: results at 30 months. J Prosthet Dent 2000;83:287-93.

13. Sato S, Hotta TH, Pedrazzi V. Removable occlusal overlay splint in the management of tooth wear: a clinical report. J Prosthet Dent 2000;83:392-5.

14. Turner KA, Missirlian DM. Restoration of the extremely worn dentition. J Prosthet Dent 1984;52: 467-74.

15. Ibbetson RJ, Setchell DJ. Treatment of the worn dentition: 2. Dent Update 1989;16:300-2, 305-7.

16. Hemmings KW, Howlett JA, Woodley NJ, Griffiths BM. Partial dentures for patients with advanced tooth wear. Dent Update 1995;22:52-9. 


\section{심하게 마모된 치열의 구치부 임플란트 식립을 통한 전악 수복 증례}

강현선, 이철원, 이원섭, 이수영*

가톨릭대학교 의과대학 서울성모병원 치과 보철과

본 증례는 심미적, 기능적 상실을 동반하여 심하게 마모가 진행된 환자의 치료에 중점을 둔다. 장기간의 구치부 지지 상 실은 포괄적인 보철 수복을 요한다. 정확한 임상적 및 방사선학적 검사, 진단 납형 제작, 수직 고경 평가 후, 임시 수복물 을 통해 환자의 적응도를 평가하였다. 8주간의 관찰기간 후에, 별다른 이상이 발견되지 않아, 최종 수복물을 제작하였다. 최종 수복물 장착 6 개월 후에도 만족스런 기능적, 심미적 결과를 얻을 수 있었다.

(구강회복응용과학지 2016;32 (3) :255-62)

주요어: 치아 마모; 수직고경; 전악수복

*교신저자: 이수영

(06591)서울 서초구 반포대로 222 가톨릭대학교 의과대학 서울성모병원 치과 보철과

Tel: 02-2258-1795 | Fax: 02-2258-2374 | E-mail: Isuyoung@daum.net

접수일: 2016년 8월 2일 | 수정일: 2016년 8월 31일 | 채택일: 2016년 9월 9일 